\title{
Isolation, molecular characterization and pathogenicity studies of infectious bursal disease field virus isolates
}

\author{
M. M. Amer ${ }^{1}$, K. M. El-Bayomi ${ }^{2}$, M. Abd-A. Kotkat ${ }^{2}$,Wafaa A. Abdel-Ghany ${ }^{1}$, M. \\ A. Shakal ${ }^{1}$, Sherein S. Abdel-Gaied ${ }^{3}$ \\ ${ }^{1}$ Poultry diseases department, Faculty Veterinary Medicine, Cairo University, ${ }^{2}$ Poultry diseases department, \\ National Research Center, ${ }^{3}$ Pathology department, Faculty Veterinary Medicine, Cairo University, Egypt.
}

\begin{abstract}
This study was carried out to investigate the prevalence, molecular characterization and pathogenicity of field infectious bursal disease virus (IBDV) isolates. Nine isolates of IBDV were isolated from 13 naturally infected broiler flocks. Detection of IBDV antigen was carried out by agar gel precipitation test (AGPT), followed by virus isolation in specific pathogen free (SPF) embryonated chicken eggs (ECE) and finally molecularly characterized and identified using reverse transcriptase polymerase chain reaction (RT-PCR). The obtained nine strains of IBDV by RT-PCR were further classified by using restriction fragment length polymorphism (RFLP) technique into (4) classical, (3) variant and (2) very virulent (vv) IBDV serotype (I). The pathogenicity of the isolated IBDV strains was detected by three passages in SPF ECEs and by experimental infection of one hundred 14 days old maternally immune layer chicks. The results showed that the mortality rate of the embryos was increased by increase the number of passages till the third passage where it reached $\mathbf{1 0 0 \%}$ for all IBDV strains and the embryos showed typical lesions of IBDV. Chicks inoculated with variant IBDV strains showed morbidity rates of 60-80 \%, without mortalities. Sacrificed birds showed atrophied bursae and thymus glands and enlarged thickened proventriculus. Groups infected with classical IBDV strains showed morbidity rates $40-60 \%$ with mortality $0-20 \%$. The detectable lesions were muscular hemorrhages with variable bursal lesions. Inoculated chicks with vvIBDV strains showed 50-70\% morbidity and mortality of rate was $30 \%$ with lesions of muscular hemorrhages, severe nephrosis with ureates in the ureters, hemorrhagic bursitis and pin point hemorrhages on the proventricular glands. Control negative non-infected group showed neither clinical signs nor mortalities along the observation period. The histopathological effect (lesion score) of IBDV strains on the bursa, spleen and thymus glands confirmed the previously mentioned results and revealed that the highest severity (score) for these organs were induced by vv IBDV strains.
\end{abstract}

Infectious bursal disease (IBD) is an acute highly contagious fatal and/or immunosuppressive viral disease of young chickens (Kibenge et al., 1988; Saif, 2003). During the 63rd General Session of the Office International des Epizooties (OIE, Paris, 15 to 19 May, 1995), IBD has been considered as socioeconomic disease at the international level, as it is present in more than $95 \%$ of the member countries (Eterradossi, 1995). The virus causing IBD has spread to essentially major poultry producing areas of the world (Faragher, 1972, Okoye, 1984; Saif et al., 2003). In Egypt, IBD was first diagnosed on the basis of its specific histological changes in the infected bursa of Fabricious by El-Sergany et al., (1974). The virus was isolated and identified from diseased 3-5 week-old broiler chickens by Ayoub and Malek (1976), followed many records on isolation and identification of the virus (Mousa et al., 1983 and 198); Amer et al., 1984 and 198;) ; El-Batrawi and El-Kady (1990). Only serotype (1) IBDV strains are virulent for chickens (Winterfield and Thacker, 1978) and displays a wide variation in pathogenic potential, this serotype replicates in and induces lyses of the IgM- bearing B-lymphocytes (Hirai et al., 1981), mainly in the bursa of fabricious, thus causing a major fatal or immunosuppressive condition in young chickens. Variant IBDV strains were first identified in 1984 s on the basis of an antigenic drift among serotype (1) (Jackwood and Saif, 1987; Saif et al., 2003).

Although variant IBDVs cause less acute signs, but have severe immunosuppressive effect and able to infect chickens with maternal derived antibody level (Muller et al., 1992). Since 1987, there was an increase in serotype (1) IBDV pathogenicity and these strains were referred as very virulent IBD (vvIBD) viruses as they induce mortalities at least twice as high as that induced by classical virus (Van den Berg et al., 1991; Eterradossi et al., 1992) and also cause severe immunosuppression as a result of severe lesions in bursa, thymus, bone marrow, spleen and caecal tonsils (Nunoya et al., 1992; Tanimura et al., 1994).

Several methods had developed for isolation and identification of IBDV. Reverse transcriptase/ polymerase chain reaction- restriction fragment length polymorphism (RT/PCR- RFLP) is considered as the most sensitive and specific technique for identification of IBDV infection as it can differentiate the viral strains into 6 molecular groups; on the basis of RFLP observed in the variable region of the VP2 gene (Jackwood and Sommer, 1997 and 1998).

Our study was designed to isolate IBDV from suspected flocks in the field, followed by molecular characterization or identification of the field isolates using RT/PCR-RFLP, then testing the pathogenicity 
of the characterized IBDV strains in both specific pathogen free embryonated chicken eggs and in 14 day-old commercial male layer chicks with maternal antibodies against IBDV.

\section{Materials and Methods}

Samples collection. Bursae were collected aseptically from 13 broiler chicken flocks suspected to be naturally infected with IBDV. These flocks represented four Egyptian governorates (El-Giza, Elqaliubia, El-Monofia and El-Behera), during the period from 2004-2005. The total number of the birds in all flocks ranged from 4700-20.000 birds of different breeds (Ross, Hubbard and Cubb). The age of the birds in these flocks ranged from 27-33 days and they suffered from lowered feed intake, stunted growth, watery diarrhea and ruffled feathers. The morbidity rate ranged from $4.8-19.6 \%$ while the mortality rate ranged from 1.22-3.92. Although the flocks were vaccinated against IBDV infection, but dead birds showed enlarged, hemorrhagic or atrophied bursae, hemorrhagic batches on the breast and thigh muscles, severe nephrosis and thickening of the proventriculus wall with hemorrhages on their glands. Table (2) summarizes the data concerning the history of the flocks suspected to be infected with IBDV infection.

Samples preparation. It was carried out according to (Anon, 1990). Bursae of each flock were pooled, homogenized in a sterile phosphate buffer saline (PBS) as $10 \%(\mathrm{~W} / \mathrm{V})$, freezed and thawed three times, and then centrifuged at $1200 \mathrm{xg}$ at $4^{\circ} \mathrm{C}$ for 15 minutes. The supernatant fluid was filtrated using $0.45 \mu-22.0 \mu$ filter paper size. Antibiotics; gentamycin and streptomycin at $50 \mathrm{mg} / \mathrm{ml}$ and $100 \mathrm{mg} / \mathrm{ml}$; respectively were added to the filtrate to avoid bacterial contamination and then kept at $-20^{\circ} \mathrm{C}$ till using in agar gel precipitation (AGP) test and in inoculation of SPF- ECE.

Agar gel precipitation test (AGPT). The prepared bursal homogenates were subjected to AGPT (Weisman and Hitchner, 1978) against positive specific hyper immune serum prepared in adult white New Zealand rabbits for IBDV detection (Nassif, 2001). Adult white New Zealand rabbits were inoculated subcutaneously and intramuscularly with 1 $\mathrm{ml}$ of concentrated antigen mixed 1:1 with complete Freund's adjuvant. A second injection of the antigen adjuvant mixture was given 10 days later by the same routes but using incomplete Freund's adjuvant. One week after the second injection a series of five intravenous inoculations administrated 3-4 days apart and consisted of $1 \mathrm{ml}$ of concentrated antigen. Rabbits were bled 10-15 days after last inoculation, then blood was obtained and serum was collected and stored at $60^{\circ} \mathrm{C}$.

Embryonated chicken eggs (ECEs) inoculation. Specific pathogen free (SPF) ECEs were obtained from SPF farm from Koum Osheim, El-Fayoum, Egypt. These eggs were used for isolation of IBDV and for testing the pathogenicity of the isolated strains. The inoculation of 10-11 day old embryos on the chorioallantoic membrane (CAM) was done according to (Hitchner, 1970).

Molecular characterization of IBDV isolates.

Preparation of viral RNA. The standard procedures mentioned by (Jackwood et al., 1996 ; Jackwood, 1997). One volume of each viral sample was extracted with an equal volume of chloroform, and the aqueous layer was collected. Sodium dodecyl sulfate (Sigma), and protein K (Sigma) were added to the final concentration of $0.5 \%$ and $1 \mathrm{mg} / \mathrm{ml}$, respectively. Following incubation at $37^{\circ} \mathrm{C}$ for 1 hour, the samples were extracted with an equal volume of acid phenol, pH 4.3 (Amresco) and then chloroform: isoamyl alcohol (24:1). The viral RNA in the aqueous phase was precipitated with ethanol and centrifuged at $10.000 \mathrm{rpm} / \mathrm{min}$. The precipitate was dissolved in $100 \mu 1$ of a $90 \%$ dimethyl sulfoxide (DMSO) solution.

Reverse transcriptase- polymerase chain reaction (RT-PCR) and restriction length polymorphism (RFLP).

Primers design. Synthesized by Metabion Company, Germany according to (Bayliss et al., 1990). (Table 1)

RT reaction (cDNA synthesis). A $2 \mu 1$ volume of viral RNA sample in DMSO was removed and amplified by RT-PCR as described by (Jackwood and Sommer, 1997). The viral RNA was denaturated at $95^{\circ} \mathrm{C}$ for 5 minutes. Then the RT reaction buffer medium containing $1 \mu \mathrm{g}$ of viral RNA, $2 \mu \mathrm{l}$ of $10 \mathrm{x}$ RT buffer, $0.5 \mathrm{mM}$ each of dNTPs, $10 \mu \mathrm{l}$ of RNase, 10 pmol. of each specific primer and $4 \mu$ reverse transcriptase enzyme in a total volume $20 \mu 1$. The mixture was incubated at $42^{\circ} \mathrm{C}$ for 1 hour. Primers (700-5 and 700-3) used in RT-PCR were designed to amplify a 743 base pair (bp) fragment of the VP2 gene from bp 701 to bp 1444 (Jackwood and Nielsen, 1997; Jackwood and Sommer, 1999). The DNA molecular weight marker was obtained from Amresco, Clevelaud, Chio, USA.

The PCR. It was carried out as previously conducted by (Nassif, 2001). The reaction mixture contained $1 \mu \mathrm{g}$ TR product, $5 \mu \mathrm{l}$ of $10 \mathrm{x}$ buffer, $2 \mu \mathrm{M}$ of each dNTPs, 30 pmol. of each primer, $2 \mathrm{mM} \mathrm{Mg} \mathrm{Cl} 2$ and $2.5 \mu$ Taq polymerase was used. The PCR was conducted using the thermal cycler in the program that involved initial denaturation at $95^{\circ} \mathrm{C}$ for 5 minutes, followed by 35 cycles of denaturation at $92^{\circ} \mathrm{C}$ for 1 minute, annealing at $50^{\circ} \mathrm{C}$ for 1 minute, extension at $72^{\circ} \mathrm{C}$ for 1 minute and final extension at $72^{\circ} \mathrm{C}$ for 10 minutes. The amplified fragment (amplicon) was visualized on 1.5\% agarose under UV illumination. A 100 bp DNA ladder marker was used. RFLP assay. RFLP assay was conducted as described by (Jackwood and Sommer, 1998). The 
Table 1: Primer sequences.

\begin{tabular}{lll}
\hline Primer & Primer Design & Position \\
\hline VP2 upstream & 5` GCGATGACAAACCTGCAAGAT 3` & $\begin{array}{l}\text { 93-114 bp according to published sequence } \\
\text { of CU-1 strain }\end{array}$ \\
VP2 downstream & 5` AGGTGGGAACATGTGGAGAC 3` & $\begin{array}{l}\text { 1470-1490 bp according to the published } \\
\text { sequence of CU-1 strain. }\end{array}$ \\
HVR upstream & 5`TCACCGTCCTCAGCTTAC 3` & $\begin{array}{l}\text { 587-604 bp according to the published } \\
\text { sequence of STC strain. } \\
\text { 1212-1229 bp according to the published } \\
\text { sequence of STC }\end{array}$ \\
\hline
\end{tabular}

obtained amplicon was firstly purified by PCR product purification kits, followed by digestion using restriction enzymes Bst NI (Stratagen) and

SspI (Roche) separately according to the manufactures instructions. One $\mu \mathrm{g}$ of each of amplicon (isolate) was mixed with $10 \mathrm{x}$ restriction enzyme buffer (Bst NI) and incubated at $50^{\circ} \mathrm{C}$ for 1 hour, while SspI was incubated at $37^{\circ} \mathrm{C}$ for 1 hour. After digestion, the restricted fragment (digested DNA by each enzyme) was separated using $2.5 \%$ agarose gel with loading of standard $100 \mathrm{bp}$ DNA ladder marker and visualized using UV transilluminator.

The pathogenicity test. The pathogenicity test of molecularly characterized IBDV strains was carried out in:

Passage in SPF-ECE/ It was done according to Hitchner (1970). Molecularly characterized IBDV strains were inoculated on the (CAM) of 10-11 day old SPF chicken embryo and three passages were performed for testing the pathogenicity.

Fourteen days old chickens. One hundred, one-dayold maternally immune male layer type (LCL) chicks were obtained from El-Wady poultry company, Giza, Egypt. The birds were fed on commercial starter balanced ration and given the feed and water adlibitum. The chicks were floor reared in separate isolated thoroughly cleaned and disinfected rooms till 14 days of age, when they divided into 10 equal groups (1-10), ten chicks each. Each group (1-9) was inoculated intraocular with $0.1 \mathrm{ml}$ of each IBDV strains, chicks of groups (1, 3 and 6) were inoculated with variant IBDV strains, birds of groups $(2,4,5$ and 7) were inoculated with classical IBDV strains, while groups (8 and 9) were inoculated with very virulent (vv) IBDV strains. Birds of group (10) were kept as control negative non-infected group. All the groups were kept under daily observation for 8 days for recording signs, mortalities and post mortem examination. At the end of the observation period, the remaining of the birds in each group were sacrificed for recording lesions and for collection of organs for histopathological examination.

Histopathological examination. Samples including bursae, spleens and thymus glands were lected separately from the dead as well as sacrificed birds in all groups at the end of the observation period. The organs were fixed in $10 \%$ buffered formalin, field isolates using RT/PCR-RFLP, then testing the pathogenicity of the characterized IBDV strains in both specific pathogen free embryonated chicken eggs and in 14 day-old commercial male layer chicks.

Table (2) showed isolation of IBDV from 9 out of 13 broiler chicken farms in different Egyptian Governorates (Middle Delta, where the poultry farms are more intensified). These flocks showed typical signs and lesions of IBDV infection. The collected bursae were taken from birds aged (27-33 days) to avoid isolation of IBDV viral vaccinal strains as these strains remain in the bird's body up to 14 days post vaccination (Winterfield et al., 1972; Vindevogel et al., 1976). Therefore, the collected samples were directed to 3 passages. Amer et al., (1984) isolated 18 strains of IBDV out of 45 chicken flocks with symptoms and post mortem lesions suspected to be IBDV infection; also, Ismail et al., (1988) isolated variant IBDV from 35-42 days old commercial Leghorn pullets vaccinated with a commercial live IBDV vaccine at 28 and 35 days of age.

By using AGPT, the suspected isolates showed positive precipitation lines with the reference IBD hyper immune sera in all tested nine flocks in the rate of (69.23) as 2, 4, 1 and 2 from El-Monofia, Giza, Behara and Kaluobia Governorates, respectively. Using of AGPT for IBDV detection was studied comprehensively by (Faragher,1972; Anon, 1990) who found that bursal homogenate from IBDV infected chickens (2- 6 day post infection) gave a better source of antigen for AGPT than the homogenate of embryonic membrane. Moreover, Saif (2003) reported that AGPT measures group specific soluble antigens but not detect serotyping difference.

Concerning the isolation of positive AGP homogenate on the CAM of SPF ECE, the homogenate gave lesions in the embryos typical and characteristic to IBDV infection. The observed gross lesions were edema, distention of abdominal region, cutaneous congestion, haemorrhages on toe joints and cerebral regions, mottled necrosis and echymotic haemorrhages on the liver. Similar lesions were recorded by (Hitchner, 1970; Lukert, 1992).

Regarding the genotypic identification and classification of IBDV isolates, the results were illustrated in figures (1, 2 and 3). From figure (1), it could be observed tat the electrophoretic pattern of the amplified IBDV isolates showed 9 out of 13 
samples were positive IBDV. These samples were given code number $(2,3,4,5,6,7,8,12$ and 13), while the other 4 samples with code number $(1,9,10$ and 11) were negative and showed no amplification of any product. Positive samples revealed the presence of specific PCR product (amplicon) at the correct expected size (642 bp) in the hypervariable region of the IBD VP2 gene. The RT-PCR technique is an exquisitely sensitive method for detection of small amount of IBDV. As it was possible to detect the virus in as little as $2 \mathrm{fg}$ of viral RNA from infected bursae after 30 cycles of PCR (Wu et al., 1992). Furthermore, this technique eliminates the need to grow or isolate IBDV before amplification, no purification steps are required to tissues before applying the technique, the total time of all procedures involved is less than 6 hours and also, this method is generally applicable to all IBDV serotypes and strains (Davis and Boyle, 1990 ; Cao et al., 1998). So, RT-PCR becomes a powerful tool in the study of the epizootiology, pathogenesis and identification of IBDV. Recently, RT-PCR is used to amplify sections of IBDV genome by several investigators (Bayliss et al., 1990; Heine et al., 1991; Wu et al., 1992; Lin et al., 1993 and 1994; Jackwood, 1994 and 1997; Liu et al., 1994; Chung et al., 1995; Jackwood and Nielsen, 1997; Jackwood and Sommer, 1997, 1998 and 1999; Khaliel and El-Lakany, 2000; Ikuta et al., 2001; Abdel-Alim et al., 2003 ; Dolz et al., 2004).

The amplified sections of the viral genome are then examined with restriction enzymes that cut the amplified DNA, resulting in a number of fragments that could be separated and visualized by electrophoresis. DNA restriction fragments forms bands on the electrophoresis gel, and the differences observed in the length of the bands from different viruses are referred to as restriction fragment length polymorphisms (RFLPs). In this study, Fig. (2) revealed the electrophretic pattern of RFLP for hyper variable region (642 bp) for VP2 gene of the nine IBDV isolates that digested with Bst NI restriction enzyme. Restriction endonuclease Bst NI enzyme digested the PCR product (642 bp) and yielded fragments of 171, 151, 110 and $210 \mathrm{bp}$, suggested classical IBDV strains (isolates with code number; 3, 5,6 and 8). The other samples were negative as they were not digested and remained as it is (642 bp), suggested variant of IBDV strains (isolates with code number; 2, 4, 7, 12 and 13). The use of Bst NI restriction enzyme for characterization and distinguish IBDV into molecular groups was previously studied by Cao et al., (1998) ; Jackwood and Sommer, (1997, 1998 and 1999) who differentiate IBDV isolates into several groups, as most of the classic strains were BstNI and StyI double positive, while most of variant strains were BstNI and StyI double negative. Added to that, Amer and Nassif (2005) genomically identified IBDV isolates from 13-
30 days old broiler chickens showing proventriculitis using RT-PCR/RELP as variant IBD viruses.

The electrophretic pattern of RFLP for hyper variable region (642 bp) for VP2 gene of the nine IBDV isolates that digested with SspI restriction enzyme was illustrated in figure (3). This SspI enzyme digested the PCR product and yielded fragment of 390 and $253 \mathrm{bp}$ indicating vvIBDV strains (isolates with code number; 12 and 13). In Egypt, was firstly reported outbreaks of vvIBDVs with variable mortality rates by El-Batrawi (1990). Sultan (1994) indicated that majority of the currently circulating IBD field viruses are highly virulent pathotype, producing acute disease with severe clinical picture and high mortalities up to $70 \%$. Bekhit (1996) attributed the severe IBD outbreaks to vvIBDV belonging to standard serotype-I. Furthermore, Abdel Alim and Saif (2001) proved that 3 vvIBDVs from Turkeys, Holland and Taiwan were antigenically related the American classical SAL strain but different from the variant strain IN and serotype-II OH strain. Moreover, Nassif (2001) who concluded that the existence of mutant vvIBDV necessitate regular scanning of field isolates to update our Egyptian data. Abdel-Alim et al., (2003) concluded that the Egyptian strains have RFLP profiles similar to the European vvIBD viruses and these strains cause severe out breaks of IBDV despite vaccination as these strains are able to break through high levels of maternal antibodies.

Strains that not digested by Bst NI and SspI restriction enzymes were considered as variant IBDV (isolates with code number; 2, 4 and 7). Ture et al., (1998) used Bst NI, SspI and M bol restriction enzymes in RT-PCR/RFLP to characterize and compare five vvIBDVs from classical and variant strains. In addition, Jackwood and Sommer (1999) stated that the SspI restriction enzyme was useful virulence marker for IBDV and can used for detection of the vv phenotype.

Considering the results of the pathogenicity test of the isolated strains in SPF ECE, Table (3) showed that mortalities and lesions in inoculated embryos were increased by passage. The third passage induced $100 \%$ mortalities except isolate coded (2) that induced $80 \%$. Dead inoculated embryos with classical and vvIBDV strains showed typical lesions (severe congested liver and greenish coloration of the liver with mottling appearance, dwarfing embryo, splenomegally, hemorrhages on head, toes skin and along the feather tracts, edematous distension of the abdominal region and cerebral edema, while dead embryos from variant IBDV strains showed stunted growth, spleenomegally and liver necrosis. Previously mentioned results were recorded by Cho et al., (1979); McFerran et al., (1980); Lasher and Shane (1994); Saif (2003). Table (4) revealed the pathogenicity of the isolated classical, variant and vvIBDV strains in 14 days old 
male LCL layer chicks having maternal derived antibodies titer to IBDV $(1878.3 \pm 253.1)$. Groups inoculated with variant IBDV strains (code number 2, 4 and 7) showed morbidity rates of 70,80 and $60 \%$, respectively and the only detectable signs throughout the observation period were off food and lowered feed intake. No mortalities were recorded $(0 \%)$ in the all inoculated groups. The post mortem findings of the dead and sacrificed birds were atrophied bursae and thymus glands without gross inflammatory reactions and enlarged thickened proventriculus with mottled appearance. These results were in accord with these of Sharma et al., (1989); Ismail et al., (1990); Dormitorio et al., (2000); Zhou (2000) ; Shaban (2004).

On the other hand, groups experimentally infected with classical IBDV strains (code number 3, 5, 6 and 8 ) showed morbidity rates $40,60,50$ and $40 \%$, respectively with signs of watery whitish diarrhea, vent picking and ruffled feathers. Chettle et al., (1989); Van Den Berg et al., (1991); Nunoya et al., (1992) ;Tsukamoto et al., (1995) recorded similar signs in chickens infected with classical IBDV strains. The mortality rates of these groups were 0 , 10,20 and $20 \%$, respectively. Dead birds during observation period were dehydrated and showed muscular haemorrhages with variable bursal lesions (odema, enlargement and/or pin point haemorrhages on the lamellae), while sacrificed birds at the end of the experiment showed pale atrophied bursae with yellowish exudates in the lumen (Roasales et al., 1989; Tsukamato et al., 1995).

Concerning groups with code number (8 and 9) that inoculated with vvIBDV strains, the morbidity rates were 70 and 50\%; respectively; and signs were similar to these observed in classical strains infected groups. Moreover, the mortality rate was 30\% for each group. The lesions observed in both dead and sacrificed birds were muscular haemorrhages, severe nephrosis with ureates in the ureters, haemorrhagic bursitis and pin point haemorrhages on the proventricular glands. Sacrificed birds at the end of the observation period showed previously mentioned lesions in addition to severe enlargement and thickening of the proventricular walls. Presence of vvIBDV strains were reported by Chettle et al., (1989); El-Batrawi (1990), Vieltz et al., (1991) ; Zierenberg et al., (2000) as the virus was rapidly spread allover the world inducing high losses in affected 3-5 weeks old chickens regardless to their previous immunity to reach $25-30 \%$ and up to $100 \%$, respectively in broilers and layers.

Control negative non-infected group (10) showed neither clinical signs nor mortalities along the observation period.
The results of histopathological examination and the lesion score of the collected organs were illustrated in plates (1,2 and 3).

Histopathological examination of stained sectioned of bursa (plate 1A), spleen (plate 3D) and thymus (plate 3A) of control negative non infected birds group showed no detected abnormalities.

Bursal sections of birds infected with IBDV classical strains (3 and 5) showed moderate lymphocytic depletion in the cortex and medulla of lymphoid follicles (plate 1B), while these infected with classical strains (6 and 8) showed vaculation of the lymphoid follicles (plate 1C). These results were also detected by Jhala et al., (1990); Dash et al., (1991) ; Khafagy et al., (1991) who found lesions of lymphocytic infiltration with necrosis of the medullary lymphocytes, also, 5 days post infection, there was bursal lymphocytic depletion and the fibrous connective tissue were proliferated.

Chickens infected with either IBD classical strains $(3,5,6$ or 8$)$ their spleen sections showed severely congested splenic vessels (plate 3E). This result was in accord with those of Ley et al., (1983); Nunoya et al., (1992) ; Hassan et al., (1996). On the other hand, thymus sections showed normal appearance (plate 3B) stated by Sharma et al., (1989); Goodwin et al., (1996); Goodwin and Hafner (1997).

Chickens infected with variant IBDV strain (2) showed apparent normal bursal follicles (plate 1D). It could be explained by the low pathogenicity of that strain as mentioned by Ismail et al., (1988) ; Jackwood et al., (1984) and (1985), where they stated that non-pathogenic isolates of IBDV didn't induce bursal lesions due to passive antibody level at time of infection which prevent or neutralize this virus. Ide (1979); Naqi et al., (1983) concluded that maternal antibodies prevent bursal damage of infected chicks at the 1 st 3 weeks of life. While those infected with IBD variant strain (4) showed atrophy of bursal lymphoid follicles and interfollicular edema associated with mononuclear leucocytic cell infiltrations (plate 2A). Infection with IBD variant strain (7) showed moderate follicular vaculation and thickening in the interfollicular stroma associated with mononuclear leucocytic cell infiltration (plate 2B). Similar findings were stated by Bracewell and Wyeth (1981); Tian et al., (1998).

Bursa of chickens inoculated with vvIBDV strains (12 or 13) showed marked vaculation of most lymphoid follicles and disintegrated of others leaving cyst like spaces containing homogenous eosinophilic material and remnant of cellular debris (plate $2 \mathrm{C}$ and 2D), as previously demonstrated by Bayoumi et al., (1984); Giambrone and Closser (1990); Nunoya et al., (1992); Thangavelu et al., (1998); Eterradossi et al., (1999). 
Table (1): Data of IBD field infected chicken flocks

\begin{tabular}{|c|c|c|c|c|c|c|c|c|}
\hline $\begin{array}{l}\text { Flock } \\
\text { No. }\end{array}$ & Locality & $\begin{array}{l}\text { Age } \\
\text { (Days) }\end{array}$ & $\begin{array}{l}\text { Total } \\
\text { No. }\end{array}$ & Breed & $\begin{array}{l}\text { Morbidity } \\
\text { rate }(\%)\end{array}$ & $\begin{array}{l}\text { Mortality } \\
\text { rate }(\%)\end{array}$ & $\begin{array}{l}\text { vaccination } \\
\text { at age/days }\end{array}$ & $\begin{array}{l}\text { Isolation, } \\
\text { AGPT\& } \\
\text { PCR }\end{array}$ \\
\hline 1 & $\begin{array}{l}\text { El- } \\
\text { Monofia }\end{array}$ & 28 & 20000 & Ross & 12.5 & 1.25 & 12 & - - \\
\hline 2 & El-Giza & 32 & 5100 & Hubbard & 19.6 & 3.92 & 15 & + \\
\hline 3 & $\begin{array}{l}\text { El- } \\
\text { Monofia }\end{array}$ & 29 & 4700 & - $\quad *$ & 16.64 & 3.19 & 12 & + \\
\hline 4 & El-Bahera & 27 & 20000 & Cobb & 17.5 & 1.5 & 12 & + \\
\hline 5 & $\begin{array}{l}\text { El- } \\
\text { Qaliubia }\end{array}$ & 33 & 15000 & Hubbard & 8.67 & 1.33 & 15 & + \\
\hline 6 & El-Giza & 27 & 12000 & Ross & 9.17 & 1.67 & 11 & + \\
\hline 7 & $\begin{array}{l}\text { El- } \\
\text { Qaliubia }\end{array}$ & 28 & 8000 & - & 14.67 & 5 & 12 & + \\
\hline 8 & El-Giza & 31 & 10000 & - & 8.5 & 2 & 16 & + \\
\hline 9 & $\begin{array}{l}\text { El- } \\
\text { monofia }\end{array}$ & 28 & 10000 & - & 7.23 & 1.22 & 14 & + \\
\hline 10 & $\begin{array}{l}\text { El- } \\
\text { Qaliubia }\end{array}$ & 30 & 10000 & Ross & 5.80 & 1.64 & 15 & - \\
\hline 11 & $\begin{array}{l}\text { El- } \\
\text { Qaliubia }\end{array}$ & 31 & 5100 & Cobb & 4.80 & 1.81 & 16 & - \\
\hline 12 & El-Giza & 32 & 12000 & - & 10 & 2.5 & 12 & + \\
\hline 13 & El-Giza & 31 & 11000 & Ross & 12.22 & 1.67 & 15 & + \\
\hline
\end{tabular}

Table (2): Results of the three passages of isolated IBDV strains

\begin{tabular}{|c|c|c|c|c|c|c|c|c|}
\hline \multirow{3}{*}{ Flock Code } & \multirow{3}{*}{$\begin{array}{l}\text { No. } \\
\text { ECE }\end{array}$} & & \multicolumn{6}{|c|}{ Passage Number } \\
\hline & & & \multicolumn{2}{|c|}{ One } & \multicolumn{2}{|c|}{ Two } & \multicolumn{2}{|c|}{ Three } \\
\hline & & & Positive ECE & $\%$ & $\begin{array}{c}\text { Positive } \\
\text { ECE }\end{array}$ & $\%$ & $\begin{array}{c}\text { Positive } \\
\text { ECE }\end{array}$ & $\%$ \\
\hline 2 & 5 & & 2 & 40 & 3 & 60 & 4 & 80 \\
\hline 3 & 5 & & 3 & 60 & 4 & 80 & 5 & 100 \\
\hline 4 & 5 & & 4 & 80 & 5 & 100 & 5 & 100 \\
\hline 5 & 5 & & 3 & 60 & 4 & 80 & 5 & 100 \\
\hline 6 & 5 & & 3 & 60 & 4 & 80 & 5 & 100 \\
\hline 7 & 5 & & 2 & 40 & 4 & 80 & 5 & 100 \\
\hline 8 & 5 & & 3 & 60 & 4 & 80 & 5 & 100 \\
\hline 12 & 5 & & 4 & 80 & 5 & 100 & 5 & 100 \\
\hline 13 & 5 & & 4 & 80 & 5 & 100 & 5 & 100 \\
\hline
\end{tabular}

Infection with both variant and vvIBDV strains caused massive necrosis in the splenic follicles (plate $3 \mathrm{~F}$ ) as well as necrosis in both cortex and medulla of thymus (plate 3C). These findings were in agreement with those of Okoye and Uzoukwu (1981); ElManakhly and Bekheit (1992); Hassan et al., (1996).

From the previously mentioned results; it could be concluded that there were great variety of IBDV (classical, variant and very virulent) subtypes of serotype (I) that distributed and circulated in our chicken farms and also these field isolates differ in their pathogenicity to maternally immunized 14 days old chickens as they can break through the maternal antibodies causing severe economic losses. The area that needs further studies is the type of IBDV antigen in live and inactivated vaccines used in Egypt and its antigenic relationship with the field viruses. 
Table (4): Results of pathogenicity testing of IBDV isolates $(n=10)$.

\begin{tabular}{|c|c|c|c|c|c|c|}
\hline $\begin{array}{l}\text { Group } \\
\text { No. }\end{array}$ & Code & Virus Type & $\begin{array}{ll}\text { No. } & \text { of } \\
\text { diseased }\end{array}$ & $\begin{array}{l}\text { Morbidity } \\
\text { rate (\%) }\end{array}$ & $\begin{array}{ll}\text { No. } & \text { of } \\
\text { dead }\end{array}$ & $\begin{array}{l}\text { Mortality } \\
\text { rate }(\%)\end{array}$ \\
\hline 1 & 2 & Variant & 7 & 70 & 0 & 0 \\
\hline 2 & 3 & Classical & 4 & 40 & 0 & 0 \\
\hline 3 & 4 & Variant & 8 & 80 & 0 & 0 \\
\hline 4 & 5 & Classical & 6 & 60 & 1 & 10 \\
\hline 5 & 6 & Classical & 3 & 30 & 2 & 20 \\
\hline 6 & 7 & Variant & 6 & 60 & 0 & 0 \\
\hline 7 & 8 & Classical & 4 & 40 & 2 & 20 \\
\hline 8 & 12 & vvIBDV & 7 & 70 & 3 & 30 \\
\hline 9 & 13 & vvIBDV & 5 & 50 & 3 & 30 \\
\hline 10 & \multicolumn{2}{|c|}{ Control negative } & - & 0.0 & 0.0 & 0.0 \\
\hline
\end{tabular}

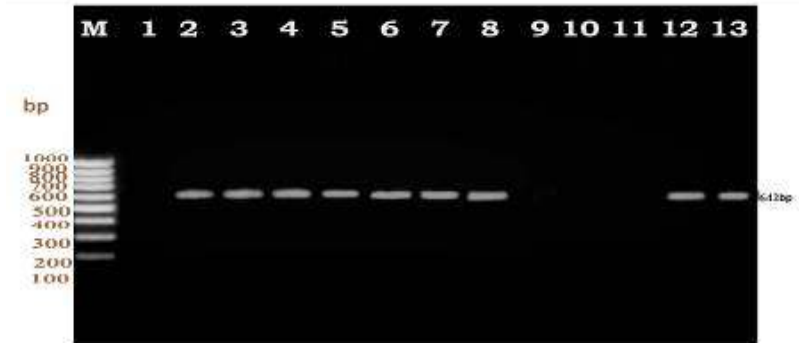

Fig. (1): Electrophoretic pattern of nested amplified PCR product of collected samples: Lane M: Marker (100 bp DNA ladder)

Lane 1, 9, 10 and 11: Showing negative samples

Lane 2, 3, 4, 5, 6, 7, 8, 12 and 13: Showing positive amplification of VP2 at (642 bp).

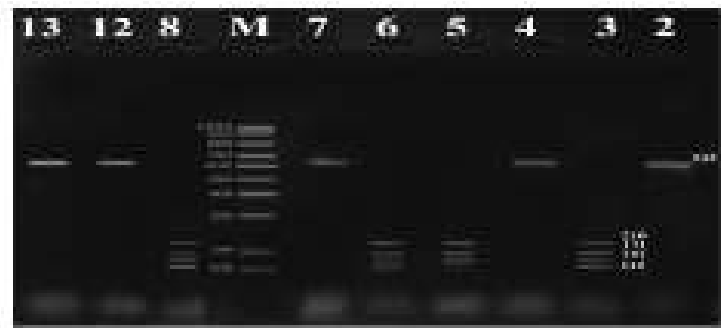

Fig. (2): Electrophoretic pattern of RFLP for the hypervariable region (642 bp) of VP2 gene of the (9) IBDV isolates digested with BstNI restriction enzyme.

Lane M: Marker (100 bp DNA ladder).

Lane 3, 5, 6 and 8: Positive result as digested and yielded fragments of 171, 151, 110 and $210 \mathrm{bp}$.

Lane 2, 4, 7, 12 and 13: Showing negative results not digested and remains as it is (642 bp)

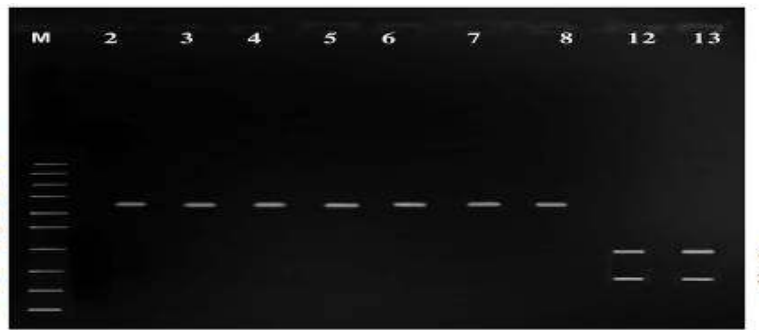

Fig. (3): Electrophoretic pattern of RFLP for the hypervariable region (642 bp) of VP2 gene of the (9) IBDV isolates digested with SspI restriction enzyme.

Lane M: Marker (100 bp DNA ladder)

Lane 12, 13: Showing positive results as it digested and yield fragment of 390 and 253 bp

Lane 2, 3, 4, 5, 6, 7 and 8: Showing negative results not digested and remain as it is (642 bp) 

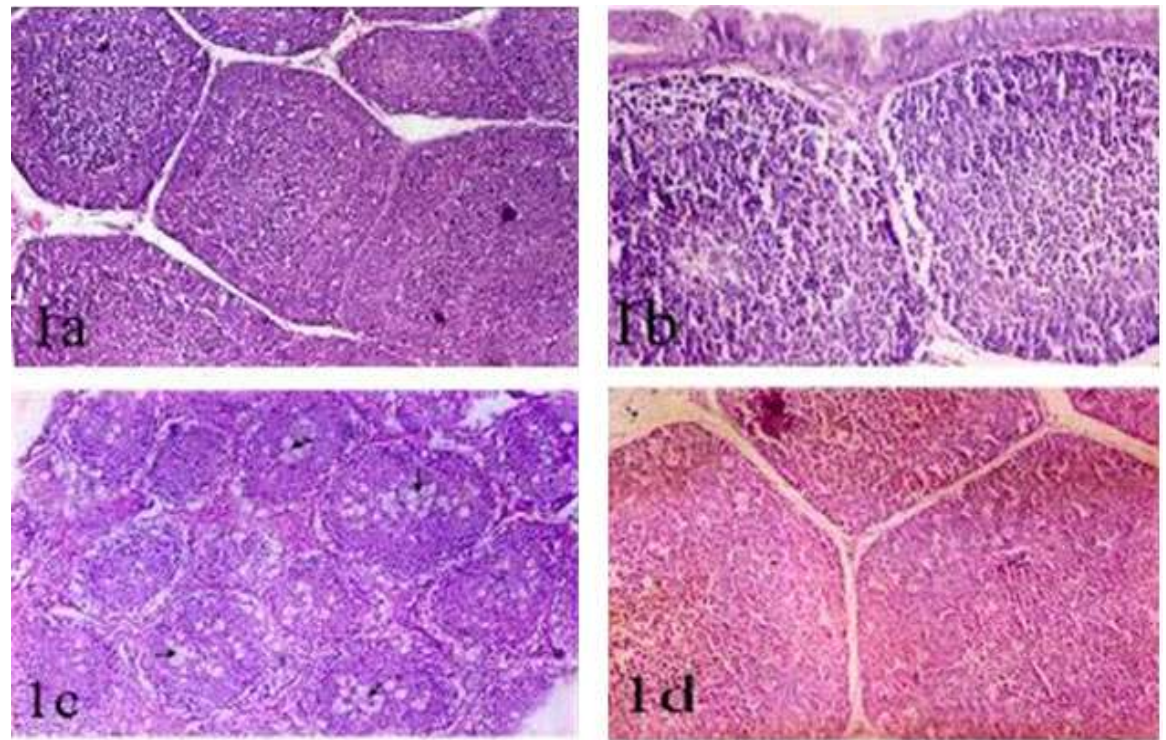

Plate (1): Bursae of control negative, classical and variant IBDV strains infected chickens:

a) Control negative showing normal follicles (Lesion score: 0 )

b) Classical strains ( 3 or 5 ) infected chickens showing moderate depletion x200 (Lesion score: 2)

c) Classical strains (6 and 8) infected chickens showing vacuolated follicles (arrow) x 100 (Lesion score: 2)
d) Variant strain
(2) infected chickens showing normal tissue x200 (Lesion score: 0 ).
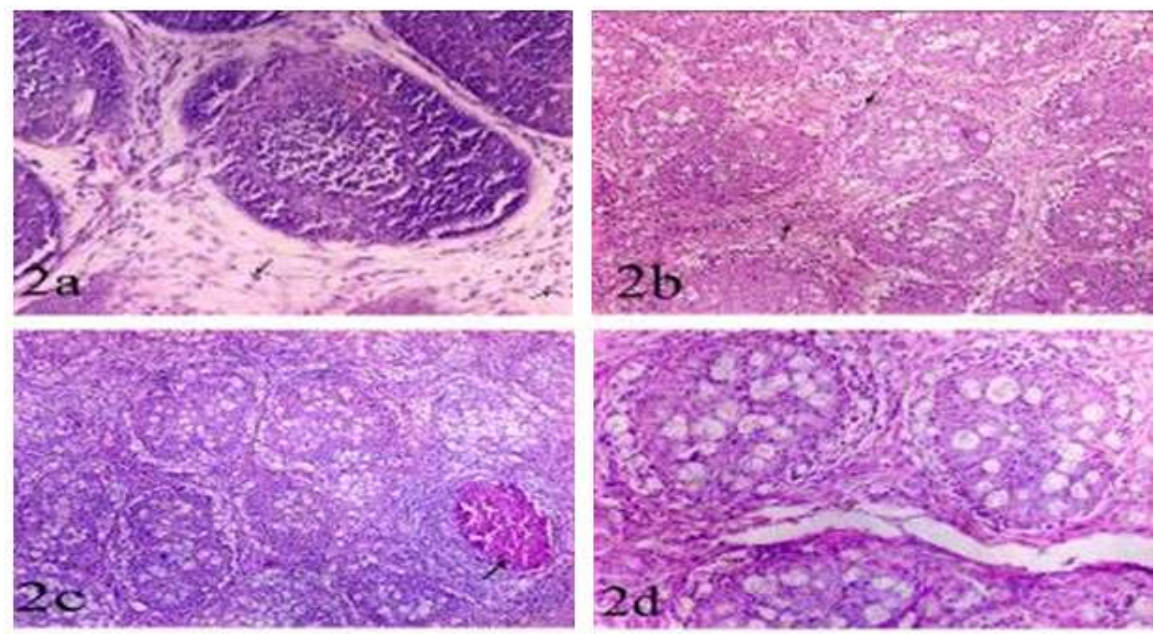

Plate (2): Bursae of variant and vvIBDV strains infected chickens

a) Variant (4) infected chickens showing leucocytic infiltration (arrow) (x200) (Lesion score: 2)

b) Variant (7) infected chickens showing vacuolated follicles and mononuclear leucocytic infiltration (arrow) (x100) (Lesion score: 2 )

c) vvIBDV $(12,13)$ infected chickens showing follicles with cyst like space containing cell debris (arrow) (x 100) (Lesion score: 4)

d) vvIBDV $(12,13)$ infected birds showing atrophied follicles (x200) (Lesion score: 4) 

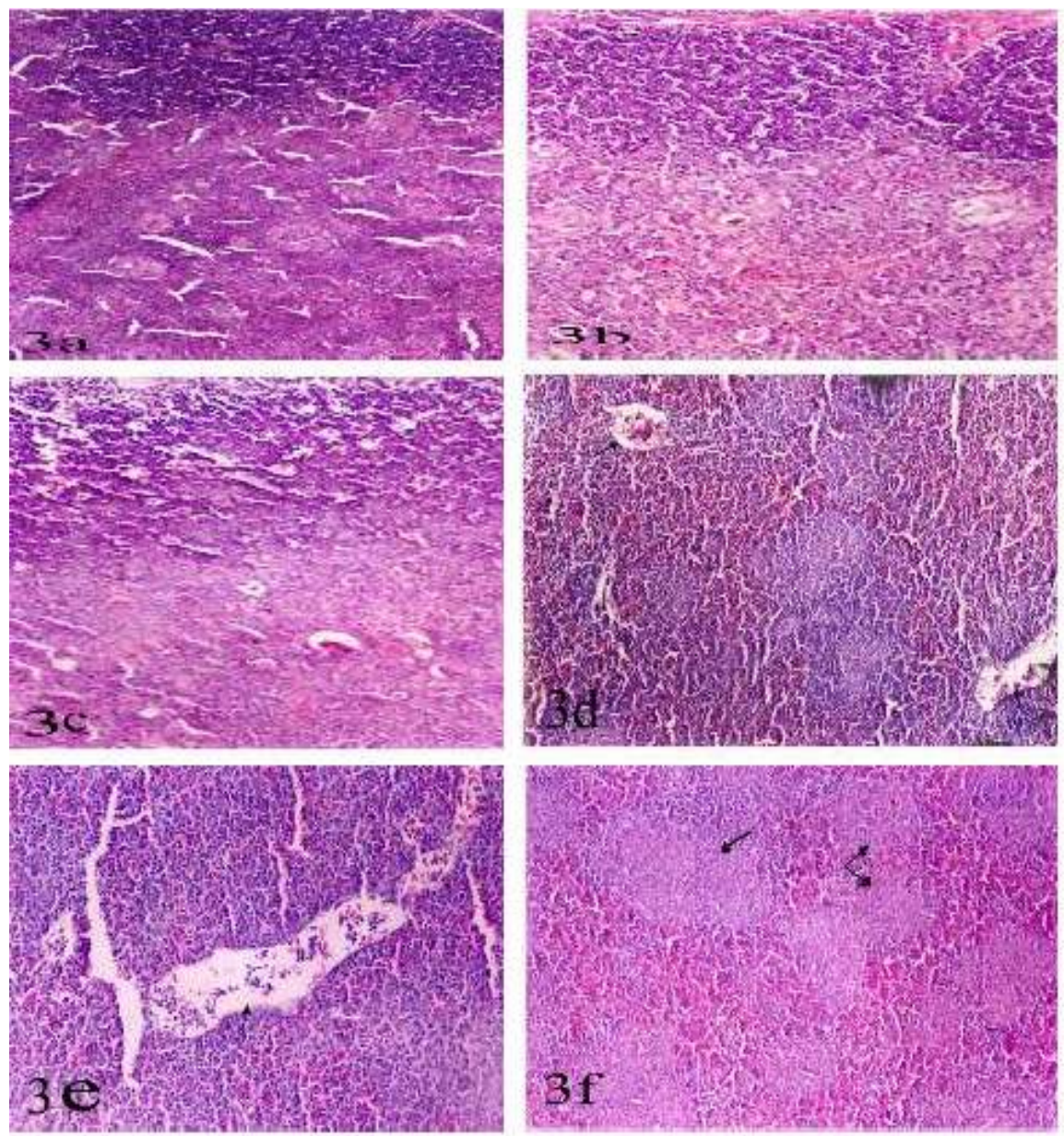

Plate (3): Sections of thymus and spleen of control negative and of infected chickens with classical, variant and vvIBDV strains (H \& E)

a) Thymus of control negative chickens showing normal tissue (x100) (Lesion score: 0 )

b) Thymus of infected chickens with classical strains showing normal tissue (x120) (Lesion score: 0 )

c) Thymus of infected chickens with vvIBD and variant strains showing necrosed cortex and medulla (x200)

(Lesion score: 3)

d) Spleen of control negative chickens showing slight congestion (arrow) (x100) (Lesion score: 1)

e) Spleen of infected chickens with classical strains showing severe congestion (arrow) (x200)

(Lesion score: 3)

f) Spleen of infected chickens with vvIBD and variant strains showing necrosed follicles (arrow)

\section{References}

Abd El-Alim, G. A. and Saif, Y. M. (2001): Immunogenicity and antigenicity of very virulent strains of infectious bursal disease viruses. Avian Dis., 45: 92-101.

Abd El-Alim, G. A.; M. H. H. Awaad and Y. M. Saif. (2003): Characterization of Egyptian field strains of infectious bursal disease virus. Avian Dis., 47: 1452-1457.

Amer, M. M.; Bastami, M. A.; and Khalifa, D. E. (1984): Studies on outbreaks of Infectious bursal disease in chickens flocks. 1Isolation and identification of causative strains. Beni-Suef Vet. Res., 5 (1/1)158171.

Amer, M. M.; Bastami, M. A.; Khalifa, D. E.; and Hamouda, A. S (1986): Serologic incidence of Gumboro disease virus infection in chickens flocks in Cairo district. Assiut Vet. Med. J., 17(33) 211-216.

Amer, M. M., and Nassif, S. A. (2005): Studies on recent IBD field variant isolates: Genomic identification and differentiation using RT-PCR-RFLP. Beni-Suef Vet. Med. J., 15, 2: 134-138.
Anon (1990): Laboratory manual for the isolation and identification of avian pathogens. $3^{\text {rd }}$ Ed., A. A. A. P. Arnold printing corporation, Itheca, New York.

Ayoub, N. N. K. and Malek, G. (1976): Der vachweis des Erregers der Gumboro disease in Egypten. Mh. Vet. Med., 31: 106-108.

Bancroft, J. D.; Steven, A. and Tuner, D. V. (1990): Theory and practice of histopathological technique. $3^{\text {rd }}$ Edn. Churchil, Living Stone edingburgh, London, Melbourne and New York.

Bayliss, C. D.; Spies, U.; Shaw, K.; Peters, R. W.; Papageorgion, A.; Muller, H. and Boursnell, M. E. C. (1990): A comparison of ences of segment A four infectious bursal disease virus strains 51 identification of a variable region in VP2. J. Gen. Virol., 71: 1303-1312.

Bayoumi, A.; Mousa, S.; Ibrahim, M. K and Deep, S. (1984): Microscopical studies of smears from tissue and blood of birds affected with infectious bursal disease. Assuit Vet. Med., 11 (22) 83-85.

Bekhit, A. B. A. (1996): Very virulent form of infectious bursal disease (vvIBD) in Egypt. $3^{\text {rd }}$ Vet. Med. Cong. Zagazig Univ.

Bracewell, C. D. and Wyeth, P. J. (1981): Infectious stunting of 
chickens. Vet. Rec., 109: 64

Cao, Y. C.; Yeung, W. S.; Law, M.; BI, Y. Z.; Leung, F. C. and Lim, B. L. (1998): Molecular characterization of seven Chinese isolates of infectious bursal disease virus: classical, very virulent, and variant strains. Avian Dis. 42: 340-351.

Chettle, N. J.; Smart, J. C. and Wyeth, P. J. (1989): Outbreak of virulent infectious bursal disease in east Anglia. Vet. Rec., 125: 271272.

Cho, B. R.; Raymond, R. G. and Hill, R. W. (1979): Growth of infectious bursal disease virus with plaque formation in chickens embryo fibroblast cell culture. Avian Dis., 23: 209-218.

Chung Yang Tsung; Yu Shaeuling; Sheih, H. K. and Lee Huw (1995): Characterization of the nucleotide sequences of the VP2 and a part of VP4 gene of infectious bursal disease virus strain P3009 isolated in Taiwan. Taiwan J. Vet. Med. Anim. Hhus., 65 (3): $205-$ 213.

Dash, B.; Verma, K. C.; Panisup, A. S.; Kataria, J. M. (1991): Pathogenicity of a field isolate of infectious bursal disease virus in chicken. Ind. J. Vet. Pathol., 15 (1) 21-25.

Dolz, R.; Majo, N.; Ordonez, G.; Ponsa, F.; Biarnes, M. and Porta R. (2004): Molecular characterization of infectious bursa disease virus isolated in Spain ab. 707., XXII WPC, June 8-13 Istanbul. Turkey.

Davis, V. D. and Boyle, J. A. (1990): Adapting the polymerase chain reaction to double stranded RNA genome. Anul. Biochem. 189: 30-43.

Dormitorio, T.V.; Giambrone, J. J.; Hoerr, F. J.; Kelly, T. F. and Lockaby, S. (2000): Is IBDV a cause of proventriculus? Highlights of Agri. Res., 47 (4), Winter 2000.

El-Batrawi, A. M. (1990): Studies on severe out breaks of infectious bursal disease. 1-The natural and experimental disease. Proc. of $2^{\text {nd }}$ Sci. Conf. Egypt. Vet. Poult., 339-252.

El-Batrawi, A. M. and El-Kady, M. F. (1990): Studies on severe outbreaks of infectious bursal disease. 3-Determination of the critical age of susceptibility in maternally immune chicks. Proceed. of $2^{\text {nd }}$ Sci. Conf. Egypt. Vet. Poult. 264-269.

El-Manakhly, E. M. and Bekheit, A. B. (1992): The pathology of broilers experimentally infected with infectious bursal disease virus and vaccination against Newcastle disease. Egypt. J. Comp. Pathol. Clin. Pathol., 5 (1): 55-64.

El-Sergany, H. A.; Ann, Moursi; Saber, M. S. and Mohammed, M. A. (1974): A preliminary investigation on the occurrence of Gumboro disease in Egypt. Egypt. J. Vet. Sci., 11-17.

Eterradossi, N. (1995): Progression the diagnosis and prophylaxis of infectious bursal disease in poultry. Comprehensive reports on technical items presented to the international committee or to regional commissions (pp. 75-82). Paris. OIE.

Eterradossi, N.; Picault, J. P.; Druin, P.; Michele Guittlet; Rolande L'hospitalier. and Bennejean, G. (1992): Pathogenicity and preliminary antigenic characterization of 6 infectious bursal disease virus strains isolated in France from acute outbreaks. J. Vet. Med. B., 39: 683-691.

Eterradossi, N.; Claire Arnauld; Tekaia, F.; Toquin, D.; Lecoq, H.; Gaelle Rivallan; Michele Guittet; Domenech, J.; Van Den Berg, T. P. and Skinner, M. A. (1999): Antigenic and genetic relationships between European very virulent infectious bursal disease viruses and early West Africa isolates. Avian pathol., 28: 36-46.

Faragher, J. T. (1972): Infectious bursal disease of chickens (review). Vet. Bull., 42 (6): 361-369.

Giambrone, J. and Closer, J. (1990): Efficacy of live vaccines against serologic serotypes of infectious bursal disease virus. Avian Dis., 37: 7-11.

Goodwin, M. A. and Hafner, S. (1997): Transmissible viral proventriculitis. In: Diseases of Poultry, $10^{\text {th }}$ Ed. Calnek, B.W. et al. (eds). Iowa State University Press, Ames, IA. Pp: 1034-1038.

Goodwin, M. A.; Hafner, S.; Bounous, D. I.; Latimer, K. S.; Player, E. C.; Niagrof, D.; Campagnoli, R. P. and Brown, J. (1996): Viral proventriculitis in chickens. Avian Pathol., 25: 369379 .

Hassan, M. K.; Al-Natour, M. Q.; Ward, L. A. and Saif, Y. M. (1996): Pathogenicity, attenuation and immunogenicity of infectious bursal disease virus. Avian Dis., 40: 567-571.

Heine, H. G.; Haritou, M.; Faille, P.; Fahey, K. and Azad, A.
(1991): Sequence analysis and expression of host-protective immunogen VP2 of variant strains of infectious bursal disease virus. Which can circumvent vaccination with standard type I strains. J. Gen. Virol., 72: 1835-1843.

Hirai, K.; Funakushi, T.; Nakai, T. and Shimakura, S. (1981): Sequential changes in the number of surface immunoglobulinbearing B lymphocytes in infectious bursal disease virus- infected chickens. Avian Dis., 25: 484-496.

Hitchner, S. B. (1970): Infectivity of infectious bursal disease virus for embryonating eggs. Poultry Sci., 49: 511-516.

Ide, P. R. (1979): Infectious bursal agent vaccination of chicks from infectious bursal agent vaccinated dams. Canad. Vet. J., 20 (2): $35-$ 40.

Ikuta, N.; EL-Attrache, J.; Villegas, P.; Garcia, M.; Lunge, R.; Fonseca, A. S. K.; Olivira, C. and Marques E. K. (2001): Molecular characterization of Brazilian infectious bursal disease virus. Avian Dis., 45: 297-306.

Ismail, N. M; Saif, Y. M. and Moorhead, P. D. (1988): Lack of pathogenicity of 5 serotype -II infectious bursal disease virus in chicken. Avian Dis., 32: 757-759.

Ismail, N. M.; Saif, Y. M.; Wigle, W. L.; Havenstein, G. B. and Jackson, C. (1990): Infectious bursal disease virus variant from commercial Leghorn pullets. Avian Dis., 34: 141-145.

Jackwood, D. J., R. J. (1994): Infectious bursal disease virus: molecular differentiation of antigenic subtypes and Jackwood among serotype I viruses. Avian Dis., 38: 531-537.

Jackwood, D. J. and Jackwood, R. J. (1997): Molecular identification of infectious bursal disease virus strains. Avian Dis., 41: 97-104.

Jackwood, D. J. and Nielsen, C. K. (1997): Detection of infectious bursal disease virus in commercaially reared chickens using the RT/PCR-RE assay. Avian Dis., 41: 137-143.

Jackwood, D. J. and Saif, Y. M. (1987): Antigenic diversity of infectious bursal disease virus. Avian Dis., 31: 766-770.

Jackwood, D. J. and Sommer, S. E. (1997): Restriction fragment length polymerphism in the VP2 gene of infectious bursal disease virus. Avian Dis., 41-637.

Jackwood, D. J. and Sommer, S. E. (1998): Genetic heterogeneity in the VP2 gene of infectious bursal disease virus detected in commercially reared chickens. Avian Dis., 42: 321-339.

Jackwood, D. J. and Sommer, S. E. (1999): Restriction fragment length polymerphism in the VP2 gene of infectious bursal disease virus from outside the United States. Avian Dis., 43: 310-314.

Jackwood, D.J.; Saif, Y. M. and Hughes, J. H. (1984): Nucleic acid and structural proteins of infectious bursal disease virus isolates belonging to serotypes I and II. Avian Dis., 28 (4): 990-1006. Jackwood, D. J.; Saif, Y. M. and Moorhead, P. D. (1985): Immunogenicity and antigenicity of infectious bursal disease virus serotype-I and II in chickens. Avian Dis., 29 (4): 1184-1194.

Jackwood, D. J.; Hanes, G. and Heins Miller, S. (1996): Infectious bursal disease viral RNA can be amplified using RT/PCR from bursa tissue following activation of the virus with phenol: chloroform. Avian Dis., 40: 457-460.

Jhala, M. K.; Kher, H. N. and Prajapati, K. S. (1990): Experimental infection of infectious bursal disease virus in chicken. Ind. J. Anim. Sci., 60 (11): 1309-1310.

Khafagy, A. K; Assia, M. El-Sawy; Kouwenhoven, B.; Vielitz, E.; Ismail, I. M.; Amer, A. A.; Sultan, H. A.; and El-Gohary, A. E. (1991): Very virulent Infectious bursal disease. Vet. Med. J. Gizza. 39 (2): 29-317

Khaliel, S. A. and El-Lakany, H. F. (2000): Molecular detection of infectious bursal disease virus in commercially reared chickens using the reverse transcriptase $/$ polymerase chain reaction-restriction endonuclease assay. Monuha Vet. J., 1 (1): 239-296.

Lasher, H. N. and Shane, S. M. (1994): Infectious bursal disease. World Poult. Sci. J., 133-166.

Ley, D. H.; Yamamoto, R. and Bickford, A. A. (1983): The pathogenesis of infectious bursal disease: Serologic, histopathologic and clinical chemical observations. Avian Dis., 27 (4): 1060-1085.

Lin, Z.; Kato, A.; Otaki, Y.; NKamura, T.; Sasmaz, E. and Veda, S. (1993): Sequence comparison of highly virulent infectious bursal disease virus prevalent in Japan. Avian Dis., 37: 315-323. Lin, T. L.; Wu, C. C.; Rosenberger, J. K. and Saif, Y. M. (1994): Rapid differentiation of infectious bursal disease virus serotypes by polymerase chain reaction. J. Vet. Diag. Inves., 6 (1) 100-102. 
Liu, H. J.; Giambrone, J. J. and Dormitorio, T. (1994): Detection of genetic variations in serotype I isolates of infectious bursal disease virus using PCR and restriction endonuclease analysis. J. Virol. Methods. 48: 281-291.

Lukert, P. D. (1992): A history of an IBD vaccine. Select laboratories Interlink 1: PP. 2 and 4.

Mousa, S.; Bayoumi, A. and Soliman, A. (1986): Infectious bursal disease in turkeys. II. Characterization of isolated virus. $2^{\text {nd }}$. Sci. Congr. Fac. Vet. Med. Assuit Univ. V. Md. J., 16 (32): 235-261.

Mousa, S.; Bayoumi, A.; Shahata, M.; and Ibrahim, A. (1983): Infectious bursal disease in Fayoumi chickens. Assuit Vet. Med. J., 10 (20): 181-185.

Muller, H.; Schnitzler, D.; Bernstein, F.; Becht, H.; Cornelissen, D. and Lutticken, D. H. (1992): Infectious bursal disease of poultry: antigenic structure of the virus and control. Vet. Microbiol., 33: 175-183.

Naqi, S. A.; Marquez, B. and Shahin, N. (1983): Maternal antibodies and its effect on infectious bursal disease immunization. Avian Dis., 27 (3) 623-630.

Nassif, S. A. A. (2001): A trial for preparation and evaluation of a local live infectious bursal disease virus vaccine. Ph.D. Thesis (Poultry Dis.) Fac. Vet. Med., Cairo Univ. Egypt.

Nunoya, T.; Otaki, Y.; Tajima, M.; Hiraga, M. and Saito, Y. (1992): Occurrence of acute infectious bursal disease with high mortality in Japan and pathogenicity of field isolates in SPF chickens. Avian Dis., 36: 597-609.

Okoye, J. O. A. (1984): Infectious bursal disease of chickens. Vet. bull., 54 (6) 425-436.

Okoye, J. O. A. and Uzoukwu. A. (1981): An outbreak of infectious bursal disease among chickens between 6 and 20 weeks old. Avian Dis., 25 (4): 1034-1038.

Roasales, A. G.; Villegas. P.; Lukert, P. D.; Fletcher, O. J. Mohamed, M. A.; and Brown, J. (1989): Isolation, identification and pathogenicity of 2 field strains of infectious bursal disease virus. Avian Dis., 33: 35-41.

Saif Y. M.; Barnes, H. J.;Fadly, A. M.; Glisson, J. R. and Swayne, D. E. (2003): Infectious bursal disease. In: Disease of Poultry, 11 th edn., Iowa State University Press. Ames, Iowa, USA. 161-180.

Shaban, K. S. (2004): Studies on avian infectious proventriculus disease. Ph.D Thesis. (Poultry Dis.), Fac. Vet. Med., Cairo Univ. Egypt.

Sharma, J. M.; Dohms, J. E. and Metz, A. L. (1989): Comparative pathogenesis of serotype-1 and variant serotype-1 isolates of infectious bursal disease virus and their effect on humera and cellular immune competence of SPF chickens. Avian Dis., 33: 112-124.

Sultan, H. A. (1994): Studies on infectious bursal disease in chickens. Ph.D. Thesis, (Poultry Dis.) Fac. Vet. Med., Alexandria University.

Tanimura, N.; Tsukamoto, K.; Naka, K.; Narita, M. and Maeda,
M. (1994): Association between pathogenicity of infectious bursal disease virus and viral antigen distribution detected by immunohistochemistry. Avian Dis., 39: 9-20.

Thangavelu, A.; Dhinakarraj, G.; Elankumaran, S.; Murali Manohar, B.; Koteeswaran A. and Venugopalan, A. T. (1998): Pathogenicity and immuno-suppressive properties of infectious bursal disease virus field isolates and commercial vaccines in India. Tropical Anim. Health and Prod., 167-176.

Tian, H. F.; Sun, L.S.; Zhu, G.Q.; Wu, L. L. and Zhu, K. X. (1998): Pathology of avian infectious proventriculitis disease in chickens, new type of avian infectious bronchitis. Chinese J. Vet. Sci., 18 (3): 237-240.

Tsukamoto, K.; Tanimura, N.; Kakita, S.; Ota, K.; Masc, M.; Imai, K. and Hihara, H. (1995): Efficacy of 3 live vaccines against highly virulent infectious bursal disease virus in chickens with or without maternal antibodies. Avian Dis., 39: 218-229.

Ture, O.; Saif, Y. M. and Jackwood, D. J. (1998): Restriction fragment length polymorphism analysis of highly virulent strains of infectious bursal disease virus from Holland, Turkey and Taiwan. Avian Dis., 42: 470-479.

Van den Berg, T. P. Gonze, M. and Meulemans, G. (1991): Acute infectious bursal disease in poultry, isolation and characterization of a highly virulent strain. Avian Pathol., 20: 133-143.

Vieltz, E.; Vob, D. M. and Conard, C. (1991): Is protection against Gumboro disease Problem? Lohmann Information 16: 6-13. Vindevogel, H.; Gouffaux, M.; Meulemans.; Duchatal, J. P. and Halen, P. (1976): Maladie de Gumboro: distribution et Persistane due virus chez le Poussing include. Etudes surla transmission de la maladie. Avian Pathol., 5: 31-38.

Weisman, J. and Hitchner, S. B. (1978): Virus neutralization, AGPT for detecting serological response to infectious bursal disease virus. Avian Dis., 22 (4): 598-603.

Winterfield, R. W. and Thacker, H. L. (1978): Immune response and pathogenicity of different strains of infectious bursal disease virus applied as vaccines. Avian Dis., 22 (4): 721-731.

Winterfield, R. W.; Fadly, A. M. and Nickford, A. (1972): Infectivity and distribution of infectious bursal disease virus in the chickens. Persistence of the virus and lesion. Avian Dis., 16 (3): 622-632.

Wu, C. C.; Lin, T. L .; Zhang, H. G.; Davis, V, S. and Boyle, J. A. (1992): Molecular detection of infectious bursal disease virus by polymerase chain reaction. Avian Dis., 36:

221-226.

Zhou, J.Y. (2000): Pathogenicity of infectious proventriculitis virus in chickens. Chinese J. Vet. Sci., 20 (2): 124-127.

Zierenberg, H. Nieper.; Van den Berg, T. P.; Ezeokoli, C. D.; Vob, M. and Muller, H. (2000): The VP2 variable region of African and German isolates of infectious bursal disease virus: comparison with very virulent "classical" virulent and attenuated tissue culture adapted strains. Arch. Virol., 145: 113-125.

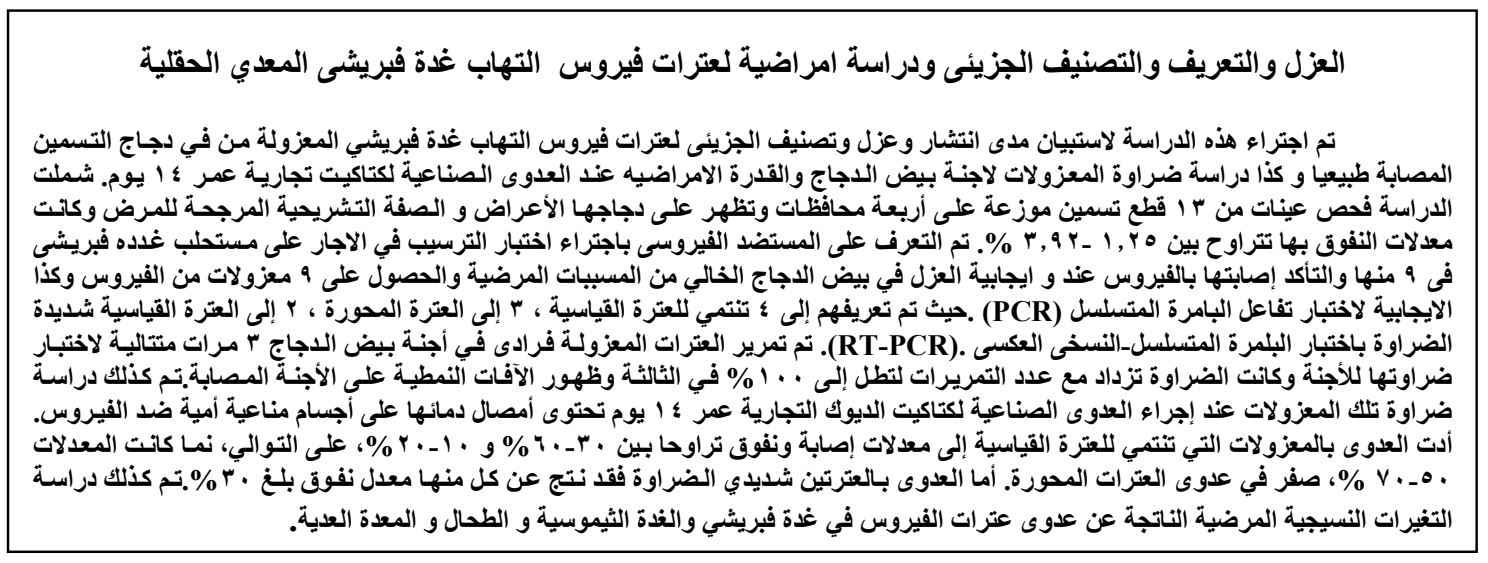


